\title{
Correction to: The wound which will not close: Jan Patočka's philosophy and the conditions of politicization
}

\author{
Daniel Leufer ${ }^{1}$
}

Published online: 9 May 2018

(C) Springer Science+Business Media B.V., part of Springer Nature 2018

\section{Correction to: Stud East Eur Thought (2017) 69:29-44 https://doi.org/10.1007/s11212-017-9273-1}

When the author wrote this article, he was working as part of the ERC project The Great War and Modern Philosophy. It has come to his attention that the article should have included the following acknowledgement.

The research leading to these results has received funding from the European Research Council under the European Union's Seventh Framework Programme (FP7/2007-2013)/ERC Grant Agreement No. 617659 (GRAPH).

The original article can be found online at https://doi.org/10.1007/s11212-017-9273-1.

Daniel Leufer

DanielJohn.Leufer@hiw.kuleuven.be

1 Husserl-Archives: Centre for Phenomenology and Continental Philosophy, Higher Institute of Philosophy, KU Leuven, Kardinaal Mercierplein 2, Box 3200, 3000 Leuven, Belgium 